\title{
Qumran e o Novo Testamento: mitos e realidades
}

\author{
Florentino García Martínez. K.U. Leuven
}

Uma das principais razões, que originou o interesse e o fascínio sobre os manuscritos de Qumran, a partir do momento de sua descoberta em 1947, foi a expectativa de que estes novos materiais poderiam iluminar os aspectos obscuros do nosso conhecimento sobre as origens e o desenvolvimento do Novo Testamento e do Cristianismo primitivo. ${ }^{1}$

Esta esperança estava bem fundamentada. Os grupos de escritos (os manuscritos do Mar Morto e o Novo Testamento) foram produzidos num período de tempo cronologicamente próximo. Os manuscritos de Qumran podem ser datados entre o século II a.C. e o ano 68 d.C., ${ }^{2}$ e os escritos do Novo Testamento originaram-se na segunda metade do século I a.C., ${ }^{3}$ quer dizer que os

\footnotetext{
* Tradução de Leonardo Agostini Fernandes, Dept ${ }^{\circ}$. Teologia PUC-Rio.

${ }^{1}$ Este dado aparece, claramente, quando se examinam os títulos das publicações que surgiram nos diferentes países durante a década de cinqüenta e sessenta do século passado. A seção mais ampla da bibliografia de B. JONGELIN, A Classified Bibliography of the Finds in the Desert of Judah (STDJ 7; Leiden, Brill 1971) está dedicada a "Qumran and the New Testament. Qumran and Christianity", pp. 111-129.

${ }^{2}$ A datação dos manuscritos, muito discutida nos inícios da investigação, não é mais alvo de disputas. As conclusões concordantes da datação paleográfica e da datação mediante o isótopo $\mathrm{C}^{14}$, aos quais foram submetidos muitos manuscritos em diversos laboratórios (graças ao desenvolvimento dos métodos do Accelerator Mass Spectometry que permitem realizar as análises com uma quantidade mínima de material), nos asseguram que, com exceção de alguns manuscritos mais antigos, a grande maioria dos manuscritos foi preparada entre o século II a.C. e o século I d.C.

${ }^{3}$ Sem entrar na discussão da datação exata de cada escrito neotestamentário, a datação global na segunda metade do século I d.C. é, geralmente, admitida.
} 
autores dos manuscritos e quem os depositou nas grutas nos arredores de Qumran e as primeiras comunidades cristãs coexistiram durante um período de tempo. Ambos os grupos podem ser localizados numa área geográfica próxima. ${ }^{4}$ Ambos os grupos se desenvolveram no mesmo contexto palestinense: uma sociedade em crise, dominada pelo império romano, desde a invasão de Pompeu no ano 63 a.C. Tanto o Novo Testamento como os manuscritos do Mar Morto são o produto de dois renovadores e semelhantes movimentos judaicos: ambos estão guiados por um líder carismático, ambos interpretam os escritos sagrados de maneira atualizadora, aplicando as profecias à própria situação; ambos encontram-se dominados por uma forte espera escatológica e se consideram vivendo no último período da história; ambos estão convencidos de que eles formam o resto eleito de Israel, a Nova Aliança do final dos tempos.

Não há nada de estranho no fato, de que uma quantidade enorme de escritos tenha sido dedicada a estudar o modo em que os manuscritos de Qumran iluminam os escritos do Novo Testamento e as origens da comunidade cristã primitiva. ${ }^{6}$ E, sem dúvida, apesar de todos esses esforços, encontramos-nos ainda muito longe de ter conseguido obter um consenso entre os investigadores sobre o que os manuscritos de Qumran nos oferecem para o conhecimento do Novo Testamento. ${ }^{7}$ Ainda mais, circulam muitas teorias descabidas e sem nenhum fundamento sobre o tema. Por isso, nesta conferência, proponho-me, em primeiro lugar, discutir algumas destas teorias, amplamente divulgadas,

\footnotetext{
${ }^{4}$ As ruínas de Qumran encontram-se a uns 25 quilômetros de Jerusalém.

${ }^{5}$ Ver a propósito, por exemplo, os capítulos "Los hombres del Mar Muerto" y "Los esenios de Qumrán, entre el dominio de la ley y la huida apocalíptica" en F. García Martínez y J. Trebolle Barrera, Los hombres de Qumrán: Literatura, estructura social y concepciones religiosas (Madrid, 1993) 45-89 [trad. portuguesa, Os homens de Qumran. Vozes, Petrópolis, 1996]

${ }^{6}$ Como exemplos de livros sobre o tema, publicados em vários idiomas, vejam-se, F. M. López Melús, El cristianismo y los Esenios de Qumrán (Madrid, 1965); M. Black, The Scrolls and Christian Origins. Studies in the Jewish Background of the New Testament (London 1961) and The Scrolls and Christianity (London, 1969); K. Stendahl, The Scrolls and the New Testament (New York, 1957); J. Daniélou, Les Manuscrits de la Mer Morte et les Origines du Christianisme (Paris, 1957); J. van der Ploeg, La Secte de Qumrân et les Origines du Christianisme (Bruges-Paris, 1959); K. H. Schelkle, Die Gemeinde von Qumran und die Kirche des Neuen Testament (Düsseldorf, 1960), e, sobretudo, a obra monumental em dois volumes de H. Braun, Qumran und das Neue Testament I, II (Tübingen, 1966).

${ }^{7}$ As duas intenções mais recentes, que eu conheço, são os dois volumes coletivos que serão publicados em breve: R. Clemens - D. Schwartz (eds.), Text, Thought, and Practice in Qumran and Early Christianituy (STDJ 84; Leiden, 2009), que contêm as atas de um simpósio organizado pelo Orion Center e o Center for the Study of Christianity da Universidade Hebraica de Jerusalém em 2004, e F. García Martínez (ed.), Echoes from the Caves: Qumran and the New Testament (STDJ 85; Leiden, 2009), com as atas de um expert meeting sobre o tema, organizado pela Universidade Católica de Leuven em 2007.
} 
para mostrar que se tratam de mitos sem algum fundamento. Em segundo lugar, apresentar-vos-ei, brevemente, a maneira adequada (na minha opinião) de se compreender as relações entre os grupos de escritos, enquanto desenvolvimentos paralelos a partir de um terreno comum aos dois, a Bíblia Hebraica. E concluirei ilustrando, com alguns exemplos, tanto sobre a prática religiosa como sobre as idéias teológicas, os efeitos, tremendamente, positivos desta forma de se compreender a relação entre os manuscritos de Qumran e o Novo Testamento.

Iniciemos por responder a algumas das perguntas mais freqüentes, que as pessoas fazem, quando se fala dos manuscritos.

a) As Igrejas cristãs teriam ocultado a evidência encontrada em Qumran para proteger seus próprios interesses?

Esta pergunta era feita por muitos, antes que a totalidade dos manuscritos tivesse sido publicada, e estava motivada, fundamentalmente, pela demora da publicação. Todavia, ainda hoje, apesar de todos os manuscritos terem sido publicados e são facilmente acessados, existem jornalistas que se interessam somente por esta questão. Os manuscritos foram descobertos, entre $1947^{8}$ e $1956 .{ }^{9}$ Até 1992 , porém, somente uma pequena parte dos manuscritos encontrados tinha sido publicada corretamente (para dar uma idéia: os 950 manuscritos fragmentados, escritos, na sua grande maioria em Hebraico e Aramaico, tinham sido publicados em 40 grandes volumes na série Discoveries in the Judaean Desert, ${ }^{10}$ mas, antes de 1992, somente tinham aparecido 8 volumes $^{11}$ ). Até 1992 , a equipe, que se ocupava com a publicação, estava formada, exclusivamente, por investigadores das distintas confissões cristãs, ${ }^{12} \mathrm{o}$ atraso da publicação atribuía-se à influência das distintas Igrejas, que temiam que o conteúdo dos manuscritos pudessem prejudicar a fé cristã.

\footnotetext{
${ }^{8}$ Em 1947 foi descoberta pelos beduínos aquela que logo será conhecida como Gruta 1, escavada pelos arqueólogos Lankster Harting e Roland de Vaux entre 15 de fevereiro e 5 de março de 1949.

${ }_{9}^{9}$ Ano em que os beduínos descobriram a Gruta 11, escavada Roland de Vaux em fevereiro do mesmo ano.

${ }^{10}$ Publicada pela Clarendon Press da Universidade de Oxford. Para uma lista completa de todos os volumes e do seu conteúdo, ver E. Tov, The Texts from the Judaean Desert: Indices and Introduction to the Discoveries in the Judaean Desert Series (DJD 39; Oxford, 2002). Os dois últimos volumes da série apareceram no final de 2008.

${ }^{11}$ Incluindo DJD 2, com textos das grutas de Murabba'at, publicado em 1961 e DJD 8, com o manuscrito grego dos Profetas Menores, proveniente de Nahal Hever ou do Wady Seyal, publicado em 1990.

${ }^{12}$ A primeira equipe internacional, dirigida por R. De Vaux, estava formada por um número maior de investigadores católicos (M. Baillet, D. Barthélemy, P. Benoit, J. T. Milik, P. W. Skehan, J. Starcky y de Vaux) e outros membros das distintas confissões cristãs: J. M. Allegro,
} 
As reais razões para o atraso eram diversas, porém, o influxo das Igrejas nada tinha a ver com elas, e não se tratava, absolutamente, da intenção de se esconder a verdade. As razões para tal atraso eram: a) de tipo técnico (a dificuldade de se unir e dar sentido ao grande número de fragmentos encontrados e que são, geralmente, de dimensões muito pequenas); b) de tipo econômico (não tinha-se feito algum preparo econômico para manter uma tal empresa, $\mathrm{e}$ os editores tinham que fazer outros trabalhos para providenciar a sua própria subsistência (eu, por exemplo, como a maioria dos outros editores, trabalhava como professor universitário, em Groningen, na Holanda); c) de tipo organizativo (a alguns dos editores foi atribuída uma grande quantidade de manuscritos, que necessitava de várias vidas para que se pudesse realizar tal tarefa); d) de tipo político (visto que a ocupação da parte Leste de Jerusalém, por Israel, complicou o trabalho no Museu de Rockefeller, onde os manuscritos estavam conservados). Portanto, fica claro e evidente, uma vez que todos os manuscritos foram publicados, que ninguém tentou ocultar nada, porque não existe nada para ser ocultado. ${ }^{13}$

Eu era um dos acusados, de não ter publicado minha parte dos manuscritos da Gruta $11 .{ }^{14}$ Acostumei-me a responder aos jornalistas, que me perguntavam a propósito do possível "cover up", com um argumento muito simples e fácil de compreender. Respondia-lhes que as Igrejas não possuíam nenhum modo de fazer pressão sobre os editores. Os únicos que podiam fazer tal pressão, sobre nós, eram os que pagavam nossos salários, e, no meu caso, era a Universidade de Groningen, uma Universidade estatal e, completamente, não confessional. Se eu tivesse algo nos manuscritos, que pudesse colocar em perigo alguma das Igrejas, eu teria sido o primeiro a publicar, visto que aceleraria minha carreira docente dentro da Universidade e nos teria feito, a mim e a minha Universidade, muito famosos. A reposta, portanto, para a primeira questão é um não muito claro.

F. M. Cross, C.H. Hunzinger e J. Strugnell. Quando foi descoberta a Gruta 11, só um dos editores encarregados pela sua publicação era católico, J. P. M. van der Ploeg; o outro editor do lote holandés, A.S. van der Woude, e os dois editores do lote americano, J. Sanders e D. N. Freedman, eram de distintas confissões cristãs.

${ }^{13}$ Contrariamente ao que afirmava a publicação sensacionalista de Michael Baigent - Richard Leigh, The Dead Sea Scrolls Deception (London 1991).

${ }^{14}$ Em 1985 van der Ploeg e van der Woude me confiaram a edição dos mansucritos da Gruta 11 ainda inéditos e em 1987 Strugnell (que sucedeu a de Vaux e a Benoit como editor chefe da Serie DJD) me encomendaram a preparação da edição DJD de todo o lote holandês da Gruta 11. O volume correspondente: Qumran Cave 11.II: 11Q2-18, 11Q20-31 (DJD 23) foi publicado em 1998. 
b) Teriam sido encontradas algumas partes do Novo Testamento entre os manuscritos?

Um grande papirólogo espanhol, José O'Callaghan, lançou, em 1972, a hipótese de que certos papiros não identificados, encontrados na Gruta 7, continham restos do que teriam sido as cópias mais antigas de distintos livros do Novo Testamento. ${ }^{15}$ O'Callaghan pretendia dizer que, nestes restos de papiros, era possível identificar partes do evangelho de Marcos, dos atos dos Apóstolos, da carta aos Romanos, da 1Timóteo e, inclusive, da 2Pedro e da carta de São Tiago. ${ }^{16}$ Estes fragmentos proporcionariam a prova de que já no ano 50 d.C., os Evangelhos e todo o Novo Testamento já tinham adquirido a forma na qual nós os conhecemos.

Trata-se de afirmações muito importantes, se tivesse sido possível provar que elas eram verdadeiras. Se a interpretação de O'Callaghan pudesse ser comprovada, de modo convincente, nos proporcionaria uma evidência concreta de que, não só, o Novo Testamento teria sido composto antes do ano 68 (ano limite para o depósito dos manuscritos nas Grutas), mas antes mesmo do ano 50 (datação paleográfica da escritura dos fragmentos). As opiniões dos críticos, que presumem um longo período de transmissão oral, antes que o Novo Testamento fosse posto por escrito, teriam sido desmentidas, como também teria sido desmentida a datação proposta, como muito mais tardia (e, geralmente, admitida pelos investigadores), para muitos dos escritos neotestamentários. Teria sido provado que o Evangelho de Marcos fora escrito, originalmente, em Grego, sem nenhuma redação prévia em Aramaico. E ter-se-ia estabelecida, de forma inquestionável, uma conexão entre os habitantes de Qumran e a comunidade cristã primitiva. ${ }^{17}$

Todavia, estas asserções são certas? Podemos nos concentrar no caso mais importante, o do fragmento 7Q5, que é o fragmento mais extenso e que se supunha correspondesse a Mc 6,52-53. Neste fragmento estão conservadas 27 letras, das quais, somente 14 são de leitura certa e não disputada. O'Callaghan lê as seis letras restantes diversamente dos demais investigado-

15 José O’Callaghan, “¿Papiros neotestamentarios en la cueva 7 de Qumrán?” Biblica 53 (1972): 91-100. O artigo foi rapidamente traduzido para o inglês por W.L. Holladay, "New Testament Papyri in Qumran Cave 7?" e distribuído como suplemento ao JBL 91/2 (1972): 1-14.

${ }^{16}$ A apresentação mais detalhada encontra-se nos dois livros de O'Callaghan dedicados ao tema: Los papiros griegos de la cueva 7 de Qumrán (BAC 353; Madrid, 1974) y Los primeros testimonios del Nuevo Testamento (Córdoba, 1995).

${ }^{17}$ As numerosas reações, positivas e negativas, à hipótese de O'Callaghan provam sua potencial importância. Uma lista detalhada está em J. A. Fitzmyer, The Dead Sea Scrolls: Major Publications and Tools for Study (Atlanta, 1990), 169-172. Para as publicações mais recentes, ver J. A. Fitzmyer, A Guide to the Dead Sea Scrolls and Related Literature (Grand Rapids, 2008), 264-267. 
res. Em si mesmo, não há nada de especial nisto. Quando somente uma parte de uma letra (em Hebraico ou Grego) fora conservada, esta pode ser lida de vários modos, porque os restos podem corresponder a diversas letras. Porém, em virtude da escassez dos restos conservados, isto já nos indica que a identificação, feita e proposta por O'Callaghan, é incerta em, pelo menos, $25 \%$ (o percentual de leituras discutidas). Além disso (e permanecendo sempre no caso de 7Q5, o fragmento mais importante da hipótese), mesmo lendo todas as letras do fragmento, como propõe O'Callaghan, a correspondência com Mc 6,52-53 só pode ser feita supondo uma variante textual (omitindo-se três letras), e que não está atestada em nenhum outro manuscrito. Isto em si, novamente, nada tem de estranho, visto que este tipo de variantes é algo freqüente em outros manuscritos. Isto, contudo, diminui, novamente, a força comprobatória do argumento. E, o que é ainda mais importante, outras identificações distintas do mesmo fragmento $7 \mathrm{Q} 5$ foram propostas para as letras conservadas (com diversos textos do Antigo Testamento ou da literatura apócrifa) que são, igualmente, possíveis, inclusive mais prováveis, porque não necessitam nem de leituras diferentes nem de variantes não atestadas, $\mathrm{e}$ que são compatíveis com os dois fragmentos da mesma Gruta, previamente identificados (7Q1 e 7Q2, partes do livro do Êxodo e da Carta de Jeremias em Grego). ${ }^{18} \mathrm{E}$ como podeis concluir, se diferentes identificações são, igualmente, possíveis, nenhuma delas pode ser considerada como definitivamente comprovada. A hipótese de O'Callaghan tem uma base tão reduzida e requer um número tão grande de fatores incertos, que sobre ela não se pode construir nada de sólido. Há algo a mais. O segundo e maior fragmento, dos não identificados da Gruta 7 (7Q4), foi identificado, por O'Callaghan, como sendo $1 \mathrm{Tm}$ $3,16-4,3^{19}$ e outro pequeno fragmento (7Q8) com Tg 1,23-24. Então, uma nova análise das fibras do papiro dos dois fragmentos, feita por E. Muro, provou que, nos dois fragmentos, as fibras têm uma inclinação característica para a direita, num ângulo de 4 graus, e que ambos os fragmentos (junto com o fragmento $7 Q 12$ não identificado por O'Callaghan) provêm, não somente do mesmo rolo, mas de colunas sucessivas dentro do rolo. ${ }^{20}$ Os três fragmentos formam, agora,

\footnotetext{
${ }^{18}$ Para um bom resumo das discussões, ver o artigo de T. J. Kraus, "7Q5: Status Quaestionis und grundlegende Anmerkungen zur Relativierung der Diskussion um das Papyrusfragment," RevQ 19/74 (1999): 239-258, e os livros de F. Rohrhirsch, Markus in Qumran? Eine Auseiandersetzung mit den Argumenten für und gegen das Fragment 7Q5 mit Hilfe des methodischen Fallibilismusprinzip (Wuppertal, 1990) e de S. Enste, Kein Markustext in Qumran: Eine Untersuchung der These: Qumran-Fragmente 7Q5=Mk 6,25-53 (NTOA 45; Freiburg, 2000).

${ }^{19}$ José O’Callaghan, “¿1 Tim 3,16; 4,1.3 en 7Q4?” Biblica 53 (1972) :362-367.

${ }^{20}$ E. A. Muro, "The Greek Fragments of Enoch from Qumran Cave $7(7 Q 4,7 Q 8$ \& $7 Q 12=$ 7QEn gr = Enoch 103:3-4, 7-8," RevQ 18/70 (1997): 307-312.
} 
um conjunto e proporcionam um número de letras superior ao que antes possuíamos, dado que facilitou, grandemente, sua identificação: os três fragmentos são provenientes duma tradução grega de 1Enoc 103,3-4 e 7-8. O argumento de Muro estimulou a investigação sobre outros fragmentos, e outros quatro já foram identificados como diferentes capítulos dessa mesma composição. ${ }^{21}$ Desde cedo, a identificação de 7Q4, 7Q8 y 7Q12 com a Epistola de Enoc não prova que a identificação de 7Q5 com o Evangelho de Marcos é incorreta ou que seja impossível. Isto, porém, reduz, ainda mais, a probabilidade de que essa identificação seja a adequada e, na minha opinião, a hipótese de O,Callaghan é muito improvável. O Novo Testamento não foi encontrado em Qumran. Entre os manuscritos gregos ali encontrados, não existe algum resto do Novo Testamento. ${ }^{22}$

\section{c) Foi Jesus Cristo um membro do grupo de Qumran?}

A pergunta é normal e apresenta-se por causa do quadro cronológico, perfeitamente, compatível, e devido à situação geográfica de Qumran (a poucos quilômetros de Jerusalém), ao que aludi, assim como pelo feito de que algumas idéias, que o Novo Testamento atribui a Jesus, são, perfeitamente, compatíveis com as que encontramos nos manuscritos. ${ }^{23}$ Visto que o Jesus do Novo Testamento aparece muito bem formado na tradição bíblica, devemos supor que ele recebeu esta formação em algum lugar, e, uma vez que o Novo Testamento nada nos diz a respeito, por que não supor que ele a tenha recebido esta formação de um grupo tão centrado na Bíblia como o da comunidade de Qumran?

A verdade, porém, é que nem o Novo Testamento alude à comunidade, que colecionou os manuscritos, nem se encontram, nestes escritos, alguma alusão à figura histórica de Jesus de Nazaré nem a nenhum outro personagem do Novo Testamento. ${ }^{24}$ Nós podemos, no máximo, fazer largas listas de seme-

\footnotetext{
${ }^{21}$ E. Puech, "Sept fragments grecs de la Lettre d' Hénoc 1 Hén 100, 103 et 105) dans la grotte 7 de Qumrân," RevQ 18/70 (1997): 313-323.

${ }^{22}$ Contrário ao que sustentam os livros sensacionalistas, como os de C. P. Thiede, The Earliest Gospel Manuscript? The Qumran Papyrus $7 Q 5$ and Its Significance for New Testament Studies (Carlisle, 1992).

${ }^{23}$ Para resolver esta pergunta, muitos livros foram dedicados. Entre os mais recentes e sensatos está o de Klaus Berger, Qumran und Jesus. Wahrheit unter Verschluss? (Stuttgart 1993) e H. Stegeman, Die Essener, Qumran, Johannes der Täufer und Jesus (Freiburg, 1993). Entre os mais descabelados e absurdos devo mencionar o livro de B. Thiering, Jesus and the Riddle of the Dead Sea Scrolls: Unlocking the Secrets of His Life (San Francisco, 1992), uma verdadeira novela de ciência-ficção, mesmo se apresentando com pretensões de seriedade científica.

${ }^{24}$ Ainda que certos investigadores, como B. Thiering ou R. Eiseman pensem que debaixo dos apelidos empregados nos manuscritos, para designar certos personagens, como o Mestre de Justiça, Sacerdote Ímpio, etc. se escondam alusões, em chave, a personagens do Novo Testamento. Ver B. E. Thiering, The Gospels and Qumran: A New Hypothesis (Sydney, 1981) y
} 
lhanças e diferenças entre o que conhecemos de Jesus de Nazaré e o que conhecemos dos manuscritos (e um grande número de livros se dedica, precisamente, a estas listas). O feito fundamental, porém, é que sobre o silêncio guardado nos textos, nós, somente, podemos tecer especulações, sem nunca poder chegar a alguma certeza. Se me permitem especular um pouco, eu me atreveria a dizer que é altamente improvável que Jesus tivesse sido um membro do grupo de Qumran ou que ele tivesse tido contato com membros deste grupo. Jesus dirige sua mensagem para todos os judeus (pecadores e justos, sem alguma distinção) e, inclusive, aos estrangeiros, que não pertencem ao povo judaico. Em Qumran, ao contrario, a mensagem se dirige, exclusivamente, aos "filhos da luz", e os judeus injustos, inclusive, são totalmente excluídos. ${ }^{25}$ Existe uma parábola muito conhecida nos Evangelhos, onde um rei convida seus amigos para celebrar as bodas de seu filho. Um a um, todos os convidados abdicam do convite, dando a sua justificativa. ${ }^{26} \mathrm{O}$ pai da casa envia, finalmente, seus servos para trazer para o banquete "os pobres, os aleijados, os coxos e os cegos", como diz Lc 14,21. Pois bem, na descrição dos que podem e dos que não podem chegar a ser membro do grupo estão, precisamente, "os cegos, os coxos e os aleijados", são os definitivamente excluídos. ${ }^{27} \mathrm{O}$ contraste não pode ser mais claro. Saber certamente, nunca saberemos, porém, parece-me muito razoável concluir que Jesus não só não foi um membro do grupo de Qumran, mas que não teve, sequer, contato com este grupo.

d) O Cristianismo primitivo se desenvolveu a partir da seita judaica dos Essênios?

Segundo a conhecida "Hipótese de Groningen", a comunidade de Qumran estava formada por um grupo que se separara do movimento dos Essênios no começo do século I a.C. e se retirara para viver só no deserto de

The Qumran Origins of the Christian Church (Sydney, 1983), ou R. Eisenman, The Dead Sea Scrolls and the First Christians (Shaftesbury, 1996).

${ }^{25}$ Sobre a idéia do "outro" nos manuscritos de Qumran ver F. García Martínez, "La memoria inventada. El 'otro' en los manuscritos de Qumran,” em J. Campos Santiago - V. Pastor Julián (eds.) Congreso internacional: "Biblia, memória histórica y encrucijada de culturas." Actas (Zamora, 2004), 49-71.

${ }^{26}$ Transmitida nos evangelhos de Mateus $(22,1-14)$ e de Lucas $(14,15-24)$

${ }^{27}$ A "Regra da Congregação" da Gruta 1 (1QSa) precisa: "E todo o que estiver contaminado em sua carne, paralisado em seus pés ou em suas mãos, coxo, cego, surdo, mudo, ou contaminado em sua carne com uma mancha visível aos olhos, ou o ancião cambaleante que não possa manter-se firme em meio à assembléia, estes não entrarão a ocupar o seu posto em meio à congregação dos homens famosos, porque os anjos de santidade estão em meio à sua congre[gação]" (1Q28a II 5-9). Texto hebraico em F. García Martínez - E. Tigchelaar, The Dead Sea Scrolls Study Edition (Leiden-Grand Rapids, 2000) I: 102. Tradução em F. García Martínez, Textos de Qumran (Madrid, 2000), 177-178 [trad. em português, Textos de Qumran, p. 171] 
Judá, na espera do final dos tempos, que se acreditava iminente. ${ }^{28}$ Que os manuscritos não mencionem nem a Jesus de Nazaré nem aos primeiros cristãos é, facilmente, compreensível, visto que o grupo de Qumran não estava interessado pelo mundo exterior e considerava todos os demais judeus como "filhos das trevas" e evitava todo tipo de contato com estranhos. Os manuscritos não mencionam, explicitamente, nem mesmo aos grupos mais importantes da época que eram os Fariseus e os Saduceus. Que o Novo Testamento não mencione o específico grupo de Qumran, um grupo marginal retirado no deserto e vivendo ali separado, tampouco é surpreendente, mesmo se no Novo Testamento sejam mencionados outros grupos diversos, aparentemente mais importantes. Mais estranho é o silêncio total do Novo Testamento sobre os Essênios, um grupo numeroso e presente em todas as cidades da Palestina, ${ }^{29}$ particularmente, quando no Novo Testamento são mencionados, com freqüência, outros grupos como os Fariseus e os Saduceus, que, junto aos Essênios, eram, aparentemente, os três partidos mais importantes da época do Novo Testamento ${ }^{30}$ Este silêncio foi interpretado, por vezes, como una intenção de encobrir as verdadeiras origens do Cristianismo, que se desenvolvera a partir do movimento Essênio. Na famosa fórmula de Ernesto Renan, "o Cristianismo é um Essenismo que teve êxito." "31

O desenvolvimento do Cristianismo, a partir do movimento Essênio, é, perfeitamente, possível, ainda que negando todo o contato de Jesus com o grupo Qumrânico. Porém, na realidade, seria o Cristianismo oriundo dessa forma particular de Judaísmo, chamada Essenismo e que, agora, conhecemos melhor, graças aos Manuscritos do Mar Morto? Minha resposta para esta pergunta também será negativa, como para as perguntas anteriores. Para que possam, porém, compreender minha resposta, é necessário que antes eu lhes apresente minha maneira de compreender a relação dos Manuscritos com o Novo Testamento.

\footnotetext{
${ }^{28}$ Formulada pela primeira vez em 1985 e publicada em F. García Martínez, "Orígenes del movimiento esenio y orígenes qumránicos. Pistas para una solución,” em V. Collado - V. Villar (eds.), II Simposio Bíblico Español (Valencia - Córdoba 1987), 527-556. Ver Los Hombres de Qumrán, 91-117. Para uma discussão recente desta hipótese, ver as contribuições contidas na quarta parte "The Groningen Hypothesis Revisited" do livro editado por G. Boccaccini, Enoch and Qumran Origins. New Light on a Forgotten Connection (Grand Rapids, 2005), 247-326.

${ }^{29}$ Segundo as informações proporcionadas pelo historiador judeu Flávio Josefo na sua obra Guerra Judía 2: § 124, e do filósofo Fílon de Alexandria na sua obra Quod omnis probus liber sit § 76.

${ }^{30}$ Como afirma Flávio Josefo, Vida §10, Guerra 2 \$119, Antigüedades 18 § 11.

${ }^{31}$ Uma definição "habiliment nuancée", como assinalava A. Dupont-Sommer, indicando que Renan não admitia que tivesse existido "commerce direct" entre os Essênios e Jesus, que acentuava que Renan falava de "un essénisme, mais pas de l'essénisme". Ver A. DupontSommer, Les écrits esséniens découverts près de la Mer Morte (Paris, 1959), 23.
} 
Durante os vinte primeiros anos de investigação sobre os manuscritos, era freqüente responder, afirmativamente, à pergunta sobre as origens essênias do Cristianismo primitivo. O melhor representante, talvez, desta maneira de compreender as coisas, foi o sábio francês André Dupont-Sommer, ${ }^{32}$ cujas opiniões foram popularizadas pelo jornalista Edmund Wilson, numa série famosa de artigos publicados no New Yorker e coletados, depois, no seu livro The Scrolls from the Dead Sea. ${ }^{33}$ Esta opinião, porém, sofria de três problemas fundamentais: a) estava fundada numa parte muito pequena dos manuscritos (os grandes manuscritos encontrados na Gruta 1 e publicados rapidamente, enquanto que a maioria dos manuscritos da Gruta 4 seguia inédito nessa direção); b) considerava todos esses manuscritos como produzidos pelos Essênios, com os que se identificava em Qumran; c) supunha-se que existiam relações diretas entre os manuscritos e o Novo Testamento ou entre os Essênios e os cristãos. $^{34}$

Agora sabemos que nenhum desses três supostos corresponde à realidade, não porque sejamos melhores do que Dupont-Sommer, mas porque possuímos muitos mais dados. Desde 1992, já não dependemos, exclusivamente, dos manuscritos da Gruta 1, mas, graças à publicação de todos os manuscritos, podemos avaliar a coleção no seu conjunto. Agora sabemos, que só uma parte, muito pequena de manuscritos, tinha sido escrita pela gente que vivia em $\mathrm{Qu}-$ mran, e que a grande maioria não contém nenhum elemento que possa ser considerado como "qumrânico", "essênio", ou algo parecido. ${ }^{35}$

Visto que os manuscritos do Mar Morto apresentam-se como fundamentados, diretamente, na Bíblia Hebraica, são muito distintos, porém, desta Bíblia Hebraica em muitos elementos teológicos e legais, é lógico considerar essas diferenças como o resultado da evolução das idéias teológicas e das normas legais refletidas na Bíblia Hebraica que se produziram dentro do Judaísmo, em dois ou três séculos que separam a composição do último livro

\footnotetext{
32 A. Dupont-Sommer, Aperçus préliminaires sur le Manuscrits de la Mer Morte (L'Orient Ancien Illustré 4 ; Paris, 1950) y Nouveaux aperçus sur les Manuscrits de la Mer Morte (L'Orient Ancien Illustré, 5 ; Paris 1953) (traduzido para o inglês, precisamente, como The Jewish Sect of Qumran and the Essenes, London-New York, 1954).

${ }^{33}$ Edmund Wilson, The Scrolls form the Dead Sea (New York, 1955).

${ }^{34}$ Ver minha contribuição à sessão de homenagem a A. Dupont-Sommer na Académie des Inscriptions et Belles-Lettres del 14 de Noviembre de 2003, "André Dupont-Sommer et les Manuscrits de la Mer Morte," CRAI 2003, pp. 1421-1434.

${ }^{35}$ Ver F. García Martínez, "Qumrán en el siglo XXI: Cambios y perspectivas después de 50 años de estudio," MEAH. Sección de Hebreo 55 (2006) 309-334, também publicada em Anales de Teología 8/2 (2006) 5-21.
} 
da Bíblia Hebraica e a colocação dos manuscritos nas grutas de Qumran. Visto que o Novo Testamento apresenta-se como fundamentado, diretamente, no Antigo Testamento, porém, também se diferencia, claramente, dele em numerosos aspectos teológicos e legais, é, igualmente, lógico o pensar que estas diferenças reflitam as mudanças que se realizaram dentro do Judaísmo desse mesmo período. E já que não há alguma prova de relação direta entre os dois tipos de escritos (os manuscritos do Mar Morto e o Novo Testamento), uma relação genérica entre os dois não é a melhor explicação nem para as semelhanças nem para as diferenças, que aparecem em ambos. ${ }^{36}$ Portanto, eu considero a relação entre os dois corpos literários, em termos de diferentes fases da evolução, a partir de um terreno comum (a Bíblia Hebraica ou o Antigo Testamento). Eu não penso que o Cristianismo se desenvolveu a partir do movimento Essênio, mas compreendo que os dois movimentos (os Essênios tal e como nos são conhecidos através das informações de Fílon de Alexandria, de Flávio Josefo e de outros autores antigos, e o Cristianismo primitivo tal e como nos é apresentado no Novo Testamento) como expressões diferentes da realidade multiforme que era o Judaísmo palestino do século primeiro.

Entre as duas partes da Bíblia cristã, Antigo e Novo Testamento, existe uma grande diferença, não só cronológica (mais de duzentos anos), mas no desenvolvimento das idéias religiosas. No Antigo Testamento, encontramo-nos no início de um processo de desenvolvimento de determinadas idéias teológicas, que nos são apresentadas numa forma plenamente evoluída no Novo Testamento. ${ }^{37}$ Quando os primeiros manuscritos da Gruta 1 foram publicados, pareceu, claro, que algumas das idéias chaves do Novo Testamento já tinham sido desenvolvidas e encontravam-se presentes nos escritos Judaicos, que, na época, eram atribuídos aos Essênios. Era, pois, lógico o

\footnotetext{
${ }^{36}$ Estas são as bases do projeto de investigação das relações entre os Manuscritos de Qumran e o Novo Testamento que realizei em Leuven durante os últimos anos. Uma primeira apresentação foi oferecida na reunião da SNTS de Barcelona em 2003 e publicada em F. García Martínez, "Emerging Christianity and Second Temple Judaism : A 'Qumranic' Perspective," RCatT 29/2 (2004) 255-267; uma síntese final foi discutida na reunião de Leuven de Dezembro de 2007, ver "F. García Martínez, "Qumran Between the Old and the New Testament," en Echoes from the Caves (Leiden, 2009) (em impressão).

${ }^{37}$ Eu mesmo estudei o desenvolvimento de algumas destas idéias, como a "filiação" (ver F. García Martínez, "Shonship at Qumran: Between the Old and the New Testament," in Ch. Hempel - Judith M. Lieu (eds.), Biblical Traditions in Transmission. Essays in Honour of Michael Knibb (SupJSJ 111; Leiden, 2006) 109-132 e "Divine Sonship at Qumran and in Philo," Studia Philonica Annual 19 (2007): 85-99), outros colaboradores do projeto como Albert L. A. Hogeterp, estudaram outros temas, ver seus livros Paul and God's Temple (Leuven, 2006) e Expectations of the End: A Comparative Traditio-Historical Study of Eschatological, Apocalyptic and Messianic Ideas in the Dead Sea Scrolls and the New Testament (STDJ 83; Leiden: 2009).
} 
postular uma relação genética entre os Essênios e o Cristianismo. Agora sabemos que a realidade era muito mais complexa e que as fases do desenvolvimento foram muito diferentes e variadas, e sabemos que muitos dos elementos que acreditávamos próprios do Novo Testamento já se tinham desenvolvido dentro do Judaísmo e não dentro da forma concreta de Judaísmo, que chamamos "Essenismo."

Por isto, eu não penso que os Manuscritos do Mar Morto nos possam mostrar que o Cristianismo se desenvolveu a partir do movimento Essênio. Os Manuscritos nos mostram que, durante os duzentos ou trezentos anos, que separam a composição do livro mais tardio da Bíblia Hebraica ou do Antigo Testamento, se produziram numerosos desenvolvimentos que foram colocados por escrito. Todavia, como a grande maioria destes escritos se perderam, tais desenvolvimentos eram-nos, totalmente, desconhecidos. Com a descoberta e a publicação dos manuscritos de Qumran, conhecemos, ao menos, uma parte destes desenvolvimentos e podemos compreender as semelhanças e as diferenças entre os manuscritos do Mar Morto e o Novo Testamento, não em termos de dependência genética de um grupo de escritos com relação ao outro, mas em termos de desenvolvimentos a partir de um terreno comum.

\section{III}

$\mathrm{Na}$ terceira parte desta conferência, vou tentar ilustrar minha compreensão desta relação com alguns exemplos significativos. O primeiro diz respeito ao preceito sabático, o segundo às obras do Messias e o terceiro à própria idéia que se tinha do Messias.

1) A lei sobre o sábado.

Tanto nos manuscritos de Qumran como no Novo Testamento, encontramos muitas discussões sobre a observância do repouso durante o sábado. ${ }^{38}$ Conheceis, sem dúvida, o texto de Lc 14,5, no qual Jesus, depois de curar um hidrópico, dirige-se, com uma pergunta, aos entendidos da Lei e Fariseus: "A quem de vós, se um filho cai num poço ou o boi, não os tira, imediatamente, no dia de sábado?" 39

A pergunta, realmente, surpreende para um judeu que conhece sua Bíblia, visto que Ex 20,9-10 deixa, totalmente, claro que nenhum trabalho, sem

\footnotetext{
${ }^{38}$ Ver o estudo detalhado de Lutz Doering, Schabbat. Sabbathalacha und -praxis im antiken Judentum und Urchristentum (TSAJ 78; Tübingen, 1999), e, recentemente, seu estudo "Sabbath Laws in the New Testament Gospels," em R. Bieringer, F. García Martínez, D. Pollefeyt \& P. J. Tomson (eds.), The New Testament and Rabbinic Literature (JSJS; Leiden, 2009) (em impressão). ${ }^{39}$ Sobre o texto lucano e suas origens, ver F. Neirynck, "Luke 14,1-6. Lukan Composition and Q Saying,” em Evangelica II. Collected Essays (BETL 99, Leuven, 1991), 183-204.
} 
alguma exceção, pode ser realizado durante o sábado ("não farás nenhum trabalho, nem tu, nem teu filho, nem tua filha, nem teu escravo, nem tua escrava, nem teu animal, nem o estrangeiro que está em tuas portas"). A pena pela transgressão deste preceito é a morte, como especificado em Ex 31,14-15 ("quem o profanar será castigado com a morte... Todo aquele que trabalhar no dia do sábado deverá ser morto"). O texto bíblico é, absolutamente, claro e não parece deixar muito espaço para a discussão ou interpretação. E, de fato, $1 \mathrm{Mc}$ 2,32-38 narra-nos como, durante a revolta macabaica, um grande número de judeus deixou-se aniquilar em seus esconderijos, ao invés de profanar o repouso do sábado. ${ }^{40}$ Sabemos que, depois desta matança, Matatías e os seus decidem: "Todo aquele que vier atacar-nos em dia de sábado, nós o enfrentaremos abertamente. Assim não morreremos todos, como morreram nossos irmãos em seus esconderijos." (1 Mac 2,41). Esta, porém, não era a opinião geral, e num escrito contemporâneo ao de Primeiro livro dos Macabeus, o Livro dos Jubileus expressa, precisamente, a opinião contraria, e precisa que nem sequer, em caso de guerra ou de ataque inimigo, é possível violar o descanso sabático (Jub 50,12-13). Isto nos indica uma das linhas em que se desenvolveu, dentro do judaísmo, que o preceito do repouso sabático, formulado no livro do Êxodo era a de uma observância rigorosa, na qual sequer o risco de perder a vida justificava sua ruptura. A distância entre o preceito bíblico, assim interpretado, e a posição do Novo Testamento parece infranqueável. Não obstante os textos do Novo Testamento sugiram-nos que esta não era a única forma de se interpretar o preceito. Dentro do Judaísmo rabínico posterior, onde no piqquah nepeř, a defesa da vida humana tem a primazia sobre o descanso sabático, é fácil compreender que um pode resgatar, mesmo sendo um sábado, a um filho que tenha caído num poço. Mas, como é possível entender, que um bom Fariseu e Jesus estejam de acordo, que um judeu observante possa resgatar do poço inclusive um boi que nele tenha caído?

Os manuscritos do Mar Morto podem nos ajudar, neste caso, a compreender o desenvolvimento que se alcançou dentro do Judaísmo pré-cristão, quanto à compreensão da lei do repouso sabático e nos mostram que a linha desenvolvida no Livro dos Jubileus não era a única. No Documento de Damas$c o$, que dedica duas colunas à discussão das leis sobre o sábado, adotando, geralmente, uma posição muito rigorosa, lê-se:

Que ninguém ajude a parir um animal no dia de sábado. E se o fizer cair num poço ou numa fossa, que não o tire no dia de sábado... E a todo homem vivo que cai num lugar de

\footnotetext{
${ }^{40}$ Flávio Josefo narra o mesmo episódio em Antigüedades 12 § 274-277.
} 
água ou num lugar de (...), que ninguém o tire com uma escada ou uma corda ou utensílio. (CD 11:13.16) ${ }^{41}$

Este texto nos mostra que o argumento de Jesus se enquadra, perfeitamente, com as discussões contemporâneas sobre a interpretação do preceito do repouso sabático. A discussão de Jesus com os Fariseus se encontra, sem dúvida, muito distante dos textos do Êxodo e de sua interpretação no Livro dos Jubileus, porém, bate, diretamente, com as discussões sobre a interpretação destes textos considerados como normativos. As especificações sobre o repouso sabático, nestas colunas do Documento de Damasco, começam com uma referência explícita do texto veterotestamentário: "pois isto é o que diz: Guarda o dia de sábado para santificá-lo", o que nos mostra que toda a discussão posterior, com sua casuística desenvolvida e especificada, não é outra coisa que uma explicação deste preceito fundamental. As aplicações concretas, o que se pode e o que não se pode fazer, durante o sábado, se deduzem, todas elas, deste preceito. Uma vez que se trata de uma lista de preceito, um sumário de normas a cumprir, não contém os princípios empregados para deduzi-las. Todavia, isto não é necessário no nosso caso. O texto qumrânico distingue, claramente, o caso de um animal que cai num poço e o de uma pessoa ("um homem vivo") na mesma circunstância. No caso de um animal, qualquer ação para retirá-lo do posso é considerada proibida pela lei do repouso do sábado ("que não seja retirado no sábado"). No caso de uma pessoa, a especificação, de que não se pode retirá-la com uma escada, com uma corda ou com outro objeto, indica, precisamente, que outras formas distintas usadas para retirá-la do poço não eram consideradas proibidas pela lei do sábado. $\mathrm{O}$ uso de uma escada (e por suposto seu transporte até o lugar do acidente) ou uma corda ou de qualquer outro objeto é considerado "trabalho", e, portanto, proibido durante o sábado. O texto, porém, apesar do seu rigor, reconhece que o caso de uma pessoa é distinto de um animal e para a pessoa não é excluída a possibilidade de que se possa retirála do poço com outros meios sem implicar um "trabalho". O Documento de Damasco não especifica quais são os meios permitidos, visto que se limita a assinalar os que estão proibidos; porém, a formulação jurídica empregada deixa, claramente, aberta a possibilidade de se retirar uma pessoa do poço durante o sábado, sem quebrar o repouso sabático, se é que exista uma maneira possível de se fazê-lo que não deva ser considerada como um trabalho.

\footnotetext{
${ }^{41}$ Texto hebraico em F. García Martínez - E. Tigchelaar, The Dead Sea Scrolls Study Edition (Leiden-Grand Rapids, 2000) I: 568. Tradução em F. García Martínez, Textos de Qumran (Madrid, 2000), 89 [trad. em português, Textos de Qumran, p. 84]. Para um estudo detalhado da seção sobre o sábado, ver L. H. Schiffman, The Halakhah at Qumran (SJLA 16; Leiden, 1975).
} 
Que esta seja a correta interpretação deste texto jurídico (e não o resultado da interpretação de alguém que, como eu, tenha sido educado por Jesuítas), parece-me comprovado por outro texto qumrânico, 4Q265, um texto que parece combinar a Regra da Comunidade e o Documento de Damasco e que é, certamente, posterior ao que acabo de citar. Este fragmento, da Gruta 4, indica-nos um modo concreto de se retirar uma pessoa do poço sem romper com o repouso sabático:

Que ninguém tire um animal que tiver caído [na] água no dia de sábado. Porém, se é um homem o que tiver caído na água no dia de sábado, que the jogue sua veste para subi-lo com ela (4Q265 7 I 6-8). ${ }^{42}$

Estes dois textos mostram-nos, claramente, o enorme desenvolvimento das discussões sobre a prática concreta do repouso sabático dentro do Judaísmo pré-cristão. A solução diferente oferecida, por ambos, para um mesmo problema, reflete o progresso realizado na interpretação da norma bíblica. E mostramnos que a discussão de Jesus com os Fariseus se insere, de uma forma natural, nas discussões judaicas sobre a interpretação do preceito. O relato do Evangelho de Lucas implica que os Fariseus, como o próprio Jesus, defendem uma posição distinta da que representam os manuscritos de Qumran, visto que Jesus e os Fariseus concordam com a possibilidade de se retirar tanto um animal como uma pessoa (o filho e o boi) que tenham caído no poço; a discussão, porém, se integra, perfeitamente, nas discussões sobre a interpretação do preceito bíblico da época, das que antes não tínhamos nenhuma idéia.

2) As obras do Messias

O segundo exemplo é ainda mais claro, pois reenvia, explicitamente, ao texto bíblico de base. No livro de Isaías, a libertação futura do povo do exílio está descrita como resultado das obras poderosas de Deus. Entre as numerosas metáforas utilizadas pelo profeta para simbolizar a ação divina, podemos ler, por exemplo, Is 35,5-6:

Então se abrirão os olhos dos cegos, e os ouvidos dos surdos se desobstruirão. Então o coxo saltará como o cervo, e a língua do mudo cantará canções alegres.

\footnotetext{
${ }^{42}$ Texto hebraico em F. García Martínez - E. Tigchelaar, The Dead Sea Scrolls Study Edition (Leiden-Grand Rapids, 2000) I: 548. Tradução em F. García Martínez, Textos de Qumran (Madrid, 2000), 121 [trad. em português Textos de Qumran, p. 114]. O manuscrito (que se deu o título de "4QMiscellaneous Rules") foi editado por J.M. Baumgarten em Qumran Cave 4. XXV: Halakhic Texts (DJD 35; Oxford, 1999), 57-78, pl. V-VIII.
} 
E em Is 61,1:

O espírito do Senhor Iahweh está sobre mim, porque Iahweh me ungiu; enviou-me a anunciar a boa nova aos pobres, a curar os quebrantados de coração e proclamar a liberdade aos cativos, a libertação aos presos.

Se tentarmos escutar estas palavras com os ouvidos daqueles a quem o profeta as dirigiu ou como os leitores judeus da época do Novo Testamento, eu penso que podemos dizer que o profeta, como consolo diante da realidade presente, descreve ações gloriosas que o Senhor realizará no futuro, ações que prometem ao povo um ano de graça e o final do desterro. Sua vocação como profeta consiste em anunciar esta mensagem, uma mensagem que se encontra confirmada pela unção que recebeu e pelo espírito de Iahweh que nele repousa. Estes dois elementos garantem que, no tempo devido, estas palavras se tornarão realidade, que o exílio terminará; que, como diz o profeta, chegará o tempo em que "as antigas ruínas serão reconstruídas" e a justiça de Jerusalém "reluzirá como um resplendor, e arderá sua salvação como uma tocha."

Estes dois textos de Isaías encontram-se reutilizados e citados, repetidamente, no Novo Testamento, porém, o que ali é dito é algo muito distinto do que ouvimos nas palavras de Isaías. Em Lc 4,16-21, encontramos Jesus lendo na Sinagoga de Nazaré, precisamente, o segundo texto citado de Isaías. Uma vez concluída a leitura, Jesus, simplesmente, alude: "Hoje se cumpriu aos vossos ouvidos essa passagem da Escritura." Isto equivale dizer: "O que o profeta diz, é um anúncio do que eu faço; as palavras que ele utiliza para descrever sua função como enviado para anunciar a boa nova aos pobres, significam, na realidade, o que estou fazendo como enviado e ungido" E no Evangelho de Mateus podemos ler:

João, ouvindo falar, na prisão, a respeito das obras de Cristo,
enviou-lhe alguns dos seus discípulos para lhe perguntarem:
"És tu aquele que há de vir, ou devemos esperar outro?" Je-
sus respondeu-lhe: "Ide contar a João o que ouvis e vedes:
os cegos recuperam a vista, os coxos andam, os leprosos são
purificados e os surdos ouvem, os mortos ressuscitam e os
pobres são evangelizados." (Mt 11,2-6)

Neste texto, à diferença do anterior de Lucas, as palavras de Isaías não aparecem citadas como tais, porém, seu uso é evidente, e a interpretação, que delas se faz, é a mesma que Lucas coloca nos lábios de Jesus na Sinagoga de Nazaré. A resposta de Jesus combina os elementos das duas citações do livro de Isaías, apresentando-os como a prova de que o anúncio se realizou. Além disso, 
acrescenta um novo elemento, que não aparecia, em absoluto, no texto do profeta: os mortos são ressuscitados. Na interpretação do Novo Testamento (provavelmente já na Fonte Q, visto que o relato encontra-se tanto em Mateus como em Lucas), os textos de Isaías não anunciam mais o final do exílio nem a chegada de um ano de graça, mas se referem aos tempos do Messias e servem para provar que estes tempos chegaram e que as ações que Jesus realiza são a prova de que ele é o Messias esperado. O que tinha sido apresentado como sinal da chegada do "ano da graça" é, agora, compreendido como sinal da chegada do Messias, as ações de Deus e os sinais do profeta formam, agora, o conjunto das "obras do Cristo," isto é, do Ungido, do Messias.

O Novo Testamento faz duas coisas distintas: por um lado, transpõe o significado do texto bíblico do seu contexto histórico para a época messiânica e, por outro lado, compreende as palavras do profeta como um anúncio, uma predição do que está acontecendo no presente. A distância entre o que Isaías disse e a interpretação de suas palavras, que encontramos no Novo Testamento, é tão grande como a distância que encontramos entre a interpretação das normas sobre o sábado.

Neste caso, também, os textos de Qumran permitem-nos, de algum modo, preencher esta distância, pois neles encontramos dois elementos que caracterizam a interpretação do Novo Testamento: os textos do profeta foram interpretados como um anúncio do que acontece na Comunidade e as ações anunciadas, por Isaías, foram transpostas para a era messiânica.

Um fragmento poético, publicado como "Apocalipse messiânico"43, conservado numa única cópia de meados do século I a.C., revela-nos como eram interpretadas as palavras de Isaías nos séculos anteriores ao Novo Testamento:

[pois os cé]us e a terra escutarão o seu messias. [e tudo] o que há neles não se apartará dos preceitos santos. Alentaivos, os que buscais o Senhor em seu serviço! Vacat Acaso não encontrareis nisso o Senhor, todos os que esperam em seu coração? Porque o Senhor observará os piedosos, e chamará pelo nome os justos, e sobre os pobres pousará seu espírito, e aos fiéis renovará com sua força. Pois honrará os piedosos sobre o trono da realeza eterna, libertando os prisi-

\footnotetext{
${ }^{43}$ Editado por E. Puech, em Qumrân Grotte 4. XVIII: Textes Hébreux (4Q521-4Q528, 4Q576$4 Q 579$ (DJD 25 ; Oxford, 1998), 1-38, pl. I-III. O texto foi dado ao público por Puech em 1992, ver E. Puech, "Un apocalypse messianique (4Q521)," RevQ 15/60 (1992): 475-522 e tinha sido estudado pelo mesmo autor em seu livro La croyance des Esséniens en la vie future: Inmortalité, résurrection, vie eternelle? Histoire d'une croyance dans le Judaïsme ancien (ED 23; Paris, 1993) II, 627-702.
} 
oneiros, dando a vista aos cegos, endireitando os torcidos. Para sempre aderirei aos que esperam. Em sua misericórdia ele jul[gará] e a ninguém lhe será atrasado o fruto [da obra] boa, e o Senhor operará ações gloriosas como não existiram, como ele dis[se,] pois curará os feridos, e os mortos os fará viver, anunciará boas notícias aos humildes, cumulará [os indigen]tes, conduzirá os expulsos, e aos famintos enriquecerá? (4Q521 2 ii $1-14)^{44}$

As primeiras linhas do fragmento reempregam o S1 146, as últimas citam, explicitamente, o texto de Isaías empregado no Novo Testamento. Nos dois casos, o autor introduz uma série de elementos completamente novos. Os céus e a terra escutam o Messias, uma figura que não aparece, em absoluto, no Sl 146, porém, sua presença, na primeira linha do fragmento 2 de 4Q521, condiciona toda a interpretação que o autor faz de ambos os textos. As ações de Deus, que simbolizam sua justiça e as ações de Isaías, que prometem o final do desterro, se converteram nas ações que o Senhor realizará nos tempos do Messias. Tanto S1 146 como o texto de Isaías são utilizados para expressar não mais uma promessa de restauração, mas o prêmio divino devido à fidelidade e à observância dos preceitos, com uma série de ações maravilhosas que Deus operará nos tempos do Messias.

Neste texto, já nos encontramos com uma grande parte dos elementos que nos faltavam para poder compreender o desenvolvimento efetuado na interpretação das palavras do profeta que nos mostra o Novo Testamento. As ações do Senhor, que simbolizam o final do desterro, são apresentadas no texto qumrânico como as ações gloriosas que o Senhor operará nos tempos do Messias. Pode-se discutir se, segundo este texto, as obras maravilhosas serão realizadas diretamente por Deus (como eu penso ${ }^{45}$ ), ou se o texto induz a pensar que Deus realizará estas obras através do seu Messias (como sugere Collins ${ }^{46}$ ); pode-se, igualmente, discutir se o texto fala de um ou de vários Messias, podese discutir o perfil messiânico desta ou destas figuras etc. O que está claro, porém, é que as palavras de Isaías já não são lidas como palavras de consolo para os que esperam o final do desterro, mas como uma descrição das ações

\footnotetext{
${ }^{44}$ Texto hebraico em F. García Martínez - E. Tigchelaar, The Dead Sea Scrolls Study Edition (Leiden-Grand Rapids, 2000) II: 1044. Tradução em F. García Martínez, Textos de Qumran (Madrid, 2000), 409-410 [trad. em português, Textos de Qumran, p. 440].

${ }^{45}$ F. García Martínez, "Los Mesías de Qumrán: Problemas de un traductor," Sefarad 53 (1993): 345-360.

${ }^{46}$ J. J. Collins, "The Works of the Messiah," Dead Sea Discoveries 1 (1994): 98-112 y The Scepter and the Star. The Messiahs of the Dead Sea Scrolls and Other Ancient Literature (New York, 1995).
} 
que caracterizam os dias do Messias, do ungido, a quem os céus e a terra escutarão. A transposição do significado do texto para o que Deus realizará no futuro já se encontra completamente realizada.

Além disso, este texto prova-nos que o elemento mais surpreendente da lista evangélica, a ressurreição dos mortos, que não aparece, absolutamente, em Isaías, já era considerada como uma destas obras maravilhosas que Deus realizará nos dias do Messias. E a precisão, "como ele disse", com a que o autor explicita a referência bíblica, permite-nos compreender o aludido na lista evangélica.

\section{3) A idéia do Messias}

Meu terceiro exemplo (e o último) concerne a um dos elementos chaves da teologia do Novo Testamento: a proclamação de Jesus como o Messias esperado.

Como sabeis, o Messias do Novo Testamento tem muitas facetas: é um homem, descendente de Davi; é, ao mesmo tempo, um Sacerdote que expia os pecados do mundo (o que parece implicar numa descendência aarônica ou levítica); é um profeta, como Moisés que proclama uma nova Lei; e é, ao mesmo tempo, uma figura celeste, o Filho de Deus. Tem sido muito difícil compreender, como os primeiros cristãos puderam chegar a formular a esperança numa figura tão complexa, com os poucos dados sobre a esperança messiânica que encontramos na Bíblia Hebraica.

Neste caso, também, e graças aos manuscritos do Mar Morto, podemos compreender como as sementes messiânicas, que se encontram presentes na Bíblia Hebraica, cresceram e se desenvolveram numa gama de figuras messiânicas esperadas "ao final dos tempos." ${ }^{47} \mathrm{Na}$ Regra da Comunidade, da Gruta 1, encontramos a formulação básica do messianismo qumrânico, com sua espera na vinda de três figuras:

Não se apartarão de nenhum conselho da lei para caminhar em toda obstinação de seu coração, mas serão governados pelas ordens primeiras nas quais os homens da Comunidade começarão a ser instruídos, até que venha o profeta e os messias de Aarão e Israel (1QS IX 9-11) ${ }^{48}$

\footnotetext{
${ }^{47}$ Para uma apresentação sintética de todos os textos messiânicos de Qumran, ver Los Hombres de Qumrán, 198-200, e os estudos posteriores, de J. Zimmermann, Messianische Texte aus Qumran (WUNT II/104; Tübingen, 1998) e de G. G. Xeravits, King, Priest, Prophet. Positive Eschatological Protagonist of the Qumran Library (STDJ 47; Leiden, 2003).

${ }^{48}$ Texto hebraico em F. García Martínez - E. Tigchelaar, The Dead Sea Scrolls Study Edition (Leiden-Grand Rapids, 2000) I: 90-91. Tradução em F. García Martínez, Textos de Qumran (Madrid, 2000), 60 [trad. em português, Textos de Qumran, p. 56].
} 
Neste texto, encontramos expressa, claramente, a esperança da vinda de um profeta e de dois Messias (a palavra hebraica empregada está no plural), um Messias sacerdote, da descendência aarônica, e um Messias não sacerdote, o Messias rei tradicional de descendência davídica. Neste texto, como nos outros textos messiânicos de Qumran, estas figuras individuais são, claramente, distintas umas das outras; não se trata de distintas funções de uma mesma pessoa, ou de diferentes aspectos de um mesmo Messias.

Neste texto, da Gruta 1, não encontramos a esperança na vinda de um redentor celeste, como o que aparece no texto sobre Melquisedec da Gruta $11,{ }^{49}$ porém, em outro texto aramaico, da Gruta 4, encontramos toda una série de expressões que nos são familiares pelo Evangelho de Lc 2,32-35 e que introduzem um personagem misterioso, de origem celeste, que aparece ao final da história e desencadeia a fase final da batalha escatológica que será seguida de uma paz eterna, um personagem, na minha opinião, muito familiar ao Filho do Homem que encontramos no Livro IV de Esdras e nas Parábolas de Henoc. Neste texto aramaico, 4Q246, que se conservou, unicamente, uma coluna e meia, pode-se ler:

Será denominado filho de Deus, e lhe chamarão filho do Altíssimo. Como as centelhas de uma visão, assim será o reino deles; reinarão alguns anos sobre a terra e arrasarão tudo; um povo arrasará o outro povo e uma cidade a outra cidade. Vacat. Até que se levante o povo de Deus e tudo descanse da espada. Seu reino será um reino eterno, e todos os seus caminhos em verdade e direi[to. A terra (estará) na verdade, e todos construirão a paz. Cessará a espada na terra, e todas as cidades the renderão homenagem. Ele é um Deus grande entre os deuses (?). Fará a guerra com ele; porá os povos em sua mão e arrojará todos diante dele. Seu domínio será um domínio eterno, e todos os abismos (4Q246 ii 1-9)

O texto termina aqui, e também eu devo terminar esta conferência. Não podemos, pois, discutir, em detalhes, esta figura misteriosa. Este texto, porém, nos proporciona a prova de que o elemento mais surpreendente da descrição de Jesus, enquanto Filho de Deus e Filho do Altíssimo, já tinha sido, previamente,

\footnotetext{
49 Ver F. García Martínez, "Las tradiciones sobre Melquisedec en los mansucritos de Qumrán," Biblica 81 (2000): 70-80 y E. F. Mason, 'You are a Priest Forever': Second Temple Jewish Messianism and the Priestly Christology of the Epistle to the Hebrew (STDJ 74; Leiden, 2008).

${ }^{50}$ Texto hebraico em F. García Martínez - E. Tigchelaar, The Dead Sea Scrolls Study Edition (Leiden-Grand Rapids, 2000) I: 494. Tradução em F. García Martínez, Textos de Qumran (Madrid, 2000), 186 [trad. em português, Textos de Qumran, p. 179].
} 
desenvolvido com relação à figura do Filho do Homem do texto de Daniel, que ecoa neste fragmento aramaico. A figura misteriosa do protagonista de 4Q246, àquela que se designa como filho de Deus e filho do Altíssimo, é, claramente, uma figura messiânica e está descrita com os traços do "Filho do Homem" de Daniel, de onde provêm as expressões "seu reino será um reino eterno" e "seu domínio será um domínio eterno", que nosso autor aplica ao protagonista misterioso de seu relato, ao que considera, sem dúvida alguma, como um indivíduo. Este personagem é apresentado como juiz do mundo inteiro e seu domínio se estende a todo o orbe. Sua ação terminará o período de crises precedente e introduzirá a situação de paz escatológica, o que permite compreender os títulos excelsos de "filho de Deus" e "filho do Altíssimo", que lhe são aplicados. A importância da existência deste tipo de figura messiânica, dentro do Judaísmo pré-cristão, parece-me evidente, e proporciona uma nova luz à proclamação solene do começo da carta aos Romanos:

que ele já tinha prometido por meio dos seus profetas nas Sagradas Escrituras, e que diz respeito a seu Filho, nascido da estirpe de Davi, segundo a carne, estabelecido Filho de Deus com poder por sua ressurreição dos mortos, segundo o Espírito de Santidade, Jesus Cristo nosso Senhor. (Rom 1,2-4)

Permitam-me ser totalmente claro. O que eu quero dizer-lhes, não é o que a complexa figura de Jesus de Nazaré, tal como nos é apresentada no Novo Testamento, tenha sido já antecipada e apresentada, como tal, nos manuscritos, tal e como é proposto por uma série de livros de caráter sensacionalista, como os de Michael Wise ${ }^{51}$ ou Israel Knohl. ${ }^{52} \mathrm{O}$ que eu acredito, que se pode concluir das numerosas alusões a distintas figuras messiânicas nos manuscritos do Mar Morto, é que as sementes da esperança messiânica, presentes na Bíblia Hebraica, foram-se desenvolvendo já no judaísmo précristão, no que concerne à espera da vinda de distintas figuras salvíficas: um Rei Messias, filho de Davi, um Messias sacerdotal, um Messias que expia, por "sua herança", que é o salvador "dos homens de seu quinhão", e destrói o reino de Belial na batalha escatológica e restaura a paz eterna, tal e como está apresentado em 11Q Melquisedec, e, inclusive, um Messias celeste designado como "filho de Deus", que encontramos em 4Q246. O que os auto-

\footnotetext{
${ }^{51}$ M. O. Wise, The First Messiah: Investigating the Savior Before Jesus (San Francisco, 1999).

${ }^{52}$ I. Knohl, The Messiah Before Jesus. The Suffering Servant of the Dead Sea Scrolls (Berkely, 2000).
} 
res do Novo Testamento puderam expressar sua fé em Jesus, como uma figura messiânica tão complexa, e o que seus leitores judeus puderam compreender, foi possível graças a estes desenvolvimentos prévios ao nascimento do Cristianismo.

Se me permitem resumir, numa só frase, quais são os mitos e quais são as realidades dos manuscritos do Mar Morto, em sua relação com o Novo Testamento, eu lhes diria que a maior contribuição dos manuscritos é que, de algum modo, preencheram o vazio que separava o Novo Testamento da Bíblia Hebraica e que assim nos revelaram os desenvolvimentos que se alcançaram dentro do Judaísmo, do qual o Cristianismo tomou a linguagem, a prática e a teologia que necessitava para poder se exprimir. Os manuscritos do Mar Morto não nos explicam o Novo Testamento, porém, nos permitem compreender porque o Novo Testamento expressou as crenças dos primeiros cristãos na forma em que as fez. Estes são os feitos. Todo o resto são mitos.

\begin{abstract}
First of all, this paper tries to argue some of the most divulged theories, on the subject in question, to show that they are myths without any bedding. Then, and in a brief form, it presents the adequate way (according to the author of this paper) how the relations between the two groups of writings (Qumran and the New Testament) must be understood: the two groups developed from a common source, the Hebrew Bible. Some illustrative examples are used to focus on the religious practice, on the theological ideas, and on the positive effect as a way of understanding the relationship between the manuscripts of Qumran and the New Testament.
\end{abstract}

Florentino García Martínez. K.U. Leuven was Professor of Early Judaism and Dead Sea Scrolls at the Catholic University of Leuven and at the University of Groningen where he led the Qumran Institute. He is a member of the International Team of Editors of the Dead Sea Scrolls, editorial secretary of the "Revue de Qumrân", and editor-inchief of the "Journal for the Study of Judaism". He has written numerous books and articles on the Dead Sea Scrolls. He edits the Series /Studies on the Texts of the Desert of Judah/, and / Supplements to the Journal for the Study of Judaism / (Brill) / and / Studies in the Dead Sea Scrolls and Related Literature/ (Eerdmans). 